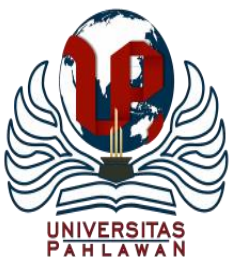

Jurnal Basicedu Volume 5 Nomor 1 Tahun 2021 Halaman 357-366

JURNAL BASICEDU

Research \& Learning in Elementary Education

https://jbasic.org/index.php/basicedu

\title{
Penerapan Model Pembelajaran Time Token Dalam Upaya Meningkatkan Keaktifan Belajar PPKn Peserta Didik di Sekolah Dasar
}

\author{
Agustinus F. Paskalino Dadi ${ }^{1}$ Maria Kewa ${ }^{2}$ \\ Program Studi PGSD, Fakultas Keguruan dan Ilmu Pendidikan, Universitas Flores ${ }^{1,2}$ \\ e-mail: dadiagustinus82@gmail.com
}

\begin{abstract}
Abstrak
Penelitian ini berangkat dari masalah rendahnya keaktifan belajar PPKn pada peserta didik kelas 5 SD GMIT Ende 4 seperti peserta didik kurang aktif dalam mengikuti pembelajaran, cenderung diam dan hanya mendengar penjelasan guru, jarang bertanya dan bertukar pikiran dengan teman dan gurunya. Tujuan penelitian ini adalah untuk mendeskripsikan proses penerapan model pembelajaran Time Token dalam pembelajaran PPKn, dan mendeskripsikan peningkatan keaktifan belajar peserta didik pada pembelajaran PPKn di kelas 5 SD GMIT Ende 4 setelah menerapkan model Time Token. Jenis penelitian yang digunakan adalah penelitian tindakan kelas yang terdiri dari 2 siklus, di mana setiap siklus menerapkan desain penelitian tindakan model Kurt Lewin berupa planning, acting, observing, dan reflecting. Pengumpulan data dilakukan dengan observasi, wawancara dan dokumentasi. Hasil penelitian menunjukkan bahwa model Time Token dapat meningkatkan keaktifan belajar PPKn pada peserta didik kelas 5 SD GMIT Ende 4. Hal ini dibuktikan dengan nilai keaktifan belajar yang mengalami peningkatan dari 39,1 (kategori sangat rendah) pada periode pratindakan menjadi 69,7 (kategori cukup) pada siklus I dan meningkat menjadi 85,4 (kategori sangat tinggi) pada siklus II. Hal ini menunjukkan bahwa model Time Token merupakan model yang tepat untuk meningkatkan keaktifan belajar peserta didik dalam pembelajaran PPKn di kelas 5 SD GMIT Ende 4.
\end{abstract}

Kata Kunci: Keaktifan Belajar, Time Token

\begin{abstract}
The problem in this study was the low level of PPKn learning activeness in grade 5 students of SD GMIT Ende 4, such as students who were less active in participating in learning, tended to be silent and only heard teacher explanations, rarely asked questions and rarely exchanged ideas with friends and teacher. The purpose of this study was to describe the process of implementing the Time Token learning model in PPKn learning, and to describe the increase in student learning activeness in PPKn learning in grade 5 SD GMIT Ende 4 after implementing the Time Token model. The type of research used is classroom action research which consists of 2 cycles, in which each cycle applies the Kurt Lewin's model of action research design in the form of planning, acting, observing, and reflecting. Data collection was carried out by observation, interviews and documentation. The results showed that the Time Token model could increase the learning activeness of PPKn in grade 5 SD GMIT Ende 4 students. This was evidenced by the value of learning activeness which increased from 39.1 (very low category) in the pre-action period to 69.7 (category sufficient) in cycle I and increased to 85.4 (very high category) in cycle II. This shows that the Time Token model is the right model to increase student learning activeness in PPKn learning at SD GMIT Ende 4.
\end{abstract}

Keywords: Learning Activeness, Time Token

Copyright (c) 2021 Agustinus F.Passkalino Dadi, Maria Kewa

Corresponding author:

Address : Universitas Flores J1. Sam Ratulangi Ende NTT ISSN 2580-3735 (Media Cetak)

Email : dadiagustinus82@gmail.com

Phone : 082145815275

ISSN 2580-1147 (Media Online)

DOI: https://doi.org/10.31004/basicedu.v5i1.703 
358 Penerapan Model Pembelajaran Time Token Dalam Upaya Meningkatkan Keaktifan Belajar PPKn Peserta Didik di Sekolah Dasar - Agustinus F.Paskalino Dadi, Maria Kewa

DOI: https://doi.org/10.31004/basicedu.v5i1.703

\section{PENDAHULUAN}

Realitas pendidikan nasional dari waktu ke waktu telah memperlihatkan dinamika yang menggembirakan. Pelbagai kemajuan dan perubahan paradigma terus terjadi seiring perkembangan pendidikan pada tataran global. Tuntutan inovasi dan kreativitas dalam aktivitas pendidikan formal menjadi suatu keharusan yang tidak dapat dinafikkan. Orientasi aktivitas pendidikan yang terpusat pada guru tidak lagi menjadi hal utama karena pendidikan dan pembelajaran di sekolah tidak lagi bernuansa transfer ilmu pengetahuan melainkan pertukaran pengetahuan. Ada aktivitas saling belajar antara guru dan peserta didik dengan memberikan ruang yang makin besar pada keaktifan dan kretavitas belajar. Belajar tidak hanya terarah pada hasil yang mau dicapai melainkan juga harus berorientasi pada proses yang menyenangkan, memungkinkan peserta didik untuk aktif, berinovasi dan berkreasi sesuai dengan potensi, minat dan bakat yang dimilikinya. Guru hadir sebagai rekan belajar dan fasilitator belajar bagi peserta didik, dan peserta didik dibimbing untuk secara aktif menemukan dan mengembangkan pengetahuan dalam setiap proses pembelajaran yang dijalaninya.

Merujuk pada perubahan paradigma dan orientasi pendidikan yang demikian, maka sudah seharusnya jika guru tidak lagi mempertahankan metode konvensional yang bersifat teacher sentered. Guru harus mampu keluar dari zona konvensionalnya untuk menerapkan suatau metode atau model baru yang menciptakan iklim keaktifan belajar peserta didik dalam setiap proses belajar yang dilaksanakan. Silberman menyatakan bahwa pembelajaran aktif meliputi berbagai cara untuk membuat peserta didik aktif sejak awal melalui aktivitas-aktivitas yang membangun kerja kelompok dan dalam waktu singkat membuat mereka berpikir tentang materi pelajaran (Shahn,
2018). Pembelajaran aktif sangat diperlukan oleh peserta didik untuk mendapatkan hasil belajar yang maksimum.

Keaktifan belajar menurut Kristin dan Astuti merupakan suatu kondisi belajar yang mencerminkan adanya keterlibatan yang aktif dari peserta didik dalam kegiatan belajar melalui aktivitas bertanya, mencari, berdiskusi, berpedapat ataupun merumsukan pemecahan terhadap masalah dalam pembelajaran (Mungzilina et al., 2018). Keaktifan belajar akan merangsang kerja akal dan kehendak peserta didik untuk menemukan pelbagai persoalan pembelajaran, mencari dan menemukan jawaban dan menyimpulkan hasil temuannya sehingga menjadi prosuk belajarnya yang komprehensif.

Keaktifan belajar peserta didik ini dapat terlihat pada beberapa karakter peserta didik berupa aktif untuk bertanya, aktif belajar dan mengerjakan tugas bersama, aktif memberikan pendapat atau bertukar pikiran, aktif untuk mencari dan menemukan jawaban atas pertanyaan yang dirumuskan, Ningzaswati menyebut beberapa indikator keaktifan belajar peserta didik seperti membentuk kelompok kecil, mengerjakan tugas bersama, bertukar pikiran dalam kelompoknya (Handayani, 2018). Keaktifan belajar juga tampak dalam beberapa indikator perilaku yang diungkapkan Sudjana (Mungzilina et al., 2018) yakni: turut serta dalam melaksanakan tugas belajar, terlibat dalam pemecahan masalah, bertanya kepada peserta didik lain atau guru, melaksnakan diskusi kelompok, melatih diri dalam pemecahan masalah.

Idealisme ini ternyata menjadi problem di SD GMIT Ende 4. Berdasarkan hasil observasi pada pembelajaran PPKn di Kelas 5, ditemukan adanya fakta bahwa peserta didik kurang aktif dan antusias dalam mengikuti pembelajaran. Peserta didik lebih banyak menghabiskan waktu 
359 Penerapan Model Pembelajaran Time Token Dalam Upaya Meningkatkan Keaktifan Belajar PPKn Peserta Didik di Sekolah Dasar - Agustinus F.Paskalino Dadi, Maria Kewa

DOI: https://doi.org/10.31004/basicedu.v5i1.703

belajarnya dengan duduk tenang mendengar penjelasan guru, jarang bertanya dan bertukar pikiran dengan teman dan gurunya. Perseta didik juga kurang mendapat ruang untuk bekerja sama dalam kelompok dan berdiskusi dengan peserta didik lainnya maupun dengan guru. Hal ini disebabkan oleh kurangnya inovasi dan kretaivitas guru dalam menggunakan metode atau model pembelajaran baru yang lebih mengaktifkan kegiatan peserta didik. Guru cenderung menggunakan metode-metode lama yang mengutamakan aktivitas guru dalam mentransfer ilmu pengetahuan. Guru menjelaskan dan berbicara dengan penuh semangat, sementara peserta didik hanya duduk dan mendengar. Terlihat jelas wajah peserta didik yang kurang bersemangat dan jenuh dengan proses pembelajaran. Hal ini kemudian berimbas pada hasil belajar yang juga kurang maksimal (hasil belajar kognitif).

Realita problematik ini mendorong peneliti untuk menawarkan suatu inovasi pembelajaran yang memberikan penguatan pada aktivitas peserta didik, berupa pemanfaatan model pembelajaran Time Token. Penguatan pada aktivitas peserta didik dalam bertanya, berdiskusi, menyampaiakan pendapat dan menyelesaiakan tugas-tugas akan membawa dampak pada tingginya keaktifan belajar peserta didik. Menurut Arends, model Time Token merupakan salah satu cooperative learning yang bertujuan agar setiap peserta didik memiliki kesempatan yang sama untuk bertanya dan memberikan pendapat, mendorong peserta didik yang pasif untuk berkontribusi aktif di dalam kelas, menghindarkan peserta didik tertentu atau guru mendominasi pembicaraan, dan mencegah adanya peserta didik yang diam saja selama proses pembelajaran (Istarani, 2012; Kandaga, 2017; Latifah, 2015; Rachmadyanti，2016; Santriana Son, 2019; Yetti, 2019).
Model Time Token diyakni dapat menjadi alternatif dalam menyelesaikan probelamtika rendahnya keaktifan belajar PPKn pada peserta didik kelas 5 SD GMIT Ende 4. Hal ini didukung oleh hasil penelitian yang membuktikan bahwa: a) model Time Token dapat meningkatkan aktivitas belajar peserta didik (Handayani, 2018; Nurhayati et al., 2014; Rachmadyanti, 2016); b) dapat meningkatkan kamampuan peserta didik dalam mengeksplorasi isi pembelajaran (Nurhasanah et al., 2013); c) keaktifan dan kemampuan dalam bertanya dan mengemukakan pendapat (Asnita \& Khair, 2020; Iriana, 2019; Mariammas et al., 2018; Nardiani et al., 2015; Oktaviani et al., 2019; Oriza et al., 2015). Dengan dasar itulah maka dalam upaya meningkatkan keaktifan belajar PPKn pada peserta didik kelas IV SD GMIT Ende 4, model pembelajaran Time Token dapat diterapkan dan dan diimpelementasikan.

\section{METODE}

Penelitian ini menggunakan jenis penelitian tindakan kelas (Class Action Research), dengan mengacu pada model penelitian tindakan kelas menurut Kurt Lewin (Ni'mah, 2017). Tahapan dalam penelitian tindakan kelas yang dilakukan meliputi: tahap planning (perencanaan), tahap acting (tindakan), tahap observing (pengamatan),

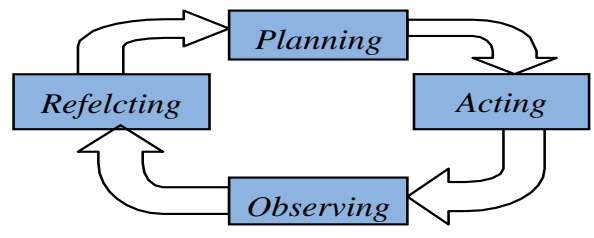

Gambar 1: Bagan PTK Model Kurt Lewin (Ni'mah, 2017)

dan tahap reflecting (refleksi). Keempat tahap ini merupakan sebuah proses yang berbentuk siklus.

Penelitian ini dilaksanakan pada bulan Juli tahun 2019 di SD GMIT Ende 4 dengan subyek penelitian adalah peserta didik kelas $5 \mathrm{~A}$ Tahun Ajaran 2019/2020 yang berjumlah 28 
360 Penerapan Model Pembelajaran Time Token Dalam Upaya Meningkatkan Keaktifan Belajar PPKn Peserta Didik di Sekolah Dasar - Agustinus F.Paskalino Dadi, Maria Kewa

DOI: https://doi.org/10.31004/basicedu.v5i1.703

orang. Teknik pengumpulan data yang digunakan adalah observasi, wawancara dan dokumentasi. Observasi dilakukan untuk mengumpulkan data tingkat keaktifan belajar peserta didik dan keterlaksanaan kegiatan pembelajaran dengan menggunakan model Time Token. Wawancara dan dokumentasi diarahkan untuk mengumpulkan data tambahan yang mendukung data hasil observasi. Teknik analisis data disesuaikan dengan jenis data yang dikumpulkan Data hasil observasi dianalisis dengan menggunakan rumus dan kategori penilaian pada tabel 1 dan 2 .

$$
\mathrm{NKB}=\frac{\mathrm{SPKB}}{\mathrm{SMKB}} \mathrm{X} 100
$$

NKB : Nilai Keaktifan Belajar

SPKB : Skor Perolehan Keaktifan Belajar

SMKB: Skor Maksimal Keaktifan Belajar

$$
\mathrm{NKP}=\frac{\mathrm{SPKP}}{\mathrm{SMKP}} \mathrm{X} 100
$$

NKP : Nilai Keterlaksanaan Pembelajaran SPKP : Skor Perolehan Keterlaksanaan Pembelajaran SMKP: Skor Maksimal Keterlaksnaan Pembelajaran

Tabel 1. Tabel Kategori Nilai Keaktifan Belajar

\begin{tabular}{ccc}
\hline No & $\begin{array}{c}\text { Tingkat Nilai Keaktifan } \\
\text { Belajar }\end{array}$ & Kriteria \\
\hline 1 & $81-100$ & Sangat Tinggi \\
2 & $71-80$ & Tinggi \\
3 & $61-70$ & Cukup \\
4 & $51-60$ & Rendah \\
5 & $<51$ & $\begin{array}{c}\text { Sangat } \\
\text { Rendah }\end{array}$ \\
\hline
\end{tabular}

Tabel 2. Tabel Kategori Keterlaksanan Pembelajaran

\begin{tabular}{ccc}
\hline No & $\begin{array}{c}\text { Nilai Keterlaksanaan } \\
\text { Pembelajaran }\end{array}$ & Kriteria \\
\hline 1 & $81-100$ & Sangat Tinggi \\
\hline 2 & $71-80$ & Tinggi \\
3 & $61-70$ & Cukup \\
4 & $51-60$ & Rendah \\
5 & $<51$ & Sangat Rendah
\end{tabular}

\section{HASIL DAN PEMBAHASAN}

Penelitian di SD GMIT Ende 4 dilaksanakan atas dasar temuan awal tentang kondisi problematik pada peserta didik Kelas 5 di dalam pembelajaran, terutama pembelajaran PPKn. Kondisi problematik dimaksud adalah rendahnya keaktifan belajar peserta didik dan hasil belajar peserta didik yang kurang maksimal. Oleh sebab itu, penelitian ini sesungguhnya berorientasi pada upaya peningkatan keaktifan belajar peserta didik kelas 5 SD GMIT Ende 4 pada pembelajaran PPKn.

Keaktifan dan hasil belajar peserta didik merupakan indikasi dari keberhasilan suatu proses pembelajaran. Jika keaktifan belajar dan hasil belajar peserta didik berada pada kategori optimal, maka proses pembelajaran yang dilaksanakan menunujukkan adanya keberhasilan. Meski demikian, yang menjadi perhatian utama di sini adalah keaktifan belajar peserta didik setelah melaksanakan pembelajaran menggunakan model Time Token. Gambaran dan uraian tentang keaktifan belajar peserta didik dalam pembelajaran PPKn setelah diterapkannya model Time Token dapat dijabarkan dalam beberapa tahapan atau bagian utama yakni kondisi awal tingkat keaktifan belajar, tingkat keaktifan belajar pada siklus I, dan tingkat keaktifan belajar pada siklus II.

Kondisi awal pembelajaran menunjukkan tingkat keaktifan belajar peserta didik yang tergolong rendah. Hal ini terlihat dari hasil observasi terhadap keaktifan belajar peserta didik dengan nilai keaktifan belajar secara keseluruhan sebesar 39,1. Nilai ini merupakan hasil pengukuran nilai keaktifan dari empat indikator keaktifan belajar, di mana masingmasing indikator memiliki nilai yang bervariasi.

Nilai keaktifan untuk indikator pertama (keinginan, keberanian menampilkan minat, 
361 Penerapan Model Pembelajaran Time Token Dalam Upaya Meningkatkan Keaktifan Belajar PPKn Peserta Didik di Sekolah Dasar-Agustinus F.Paskalino Dadi, Maria Kewa

DOI: https://doi.org/10.31004/basicedu.v5i1.703

kebutuhan dan permasalahannya) sebesar 37,72; nilai keaktifan untuk indikator kedua (keinginan dan keberanian serta kesempatan untuk berpartisipasi dalam proses pembelajaran yang berkelanjutan) adalah 41,29; nilai untuk indikator ketiga (menampilkan berbagai usaha atau kreativitas belajar dalam menjalani dan menyelesaiakan kegiatan belajar mengajar sampai mencapai keberhasilannya) sebesar 39,06; dan nilai untuk indikator keempat (kebebasan atau keleluasaan melakukan pembelajaran tanpa tekanan guru atau pihak lainnya) sebesar 38,17. Jika merujuk pada kriteria nilai keaktifan belajar maka keaktifan belajar peserta didik sebelum menggunakan model Time Token berada pada kategori sangat rendah. Nilai kakatifan belajar dapat dilihat pada gambar 2 dan 3 .

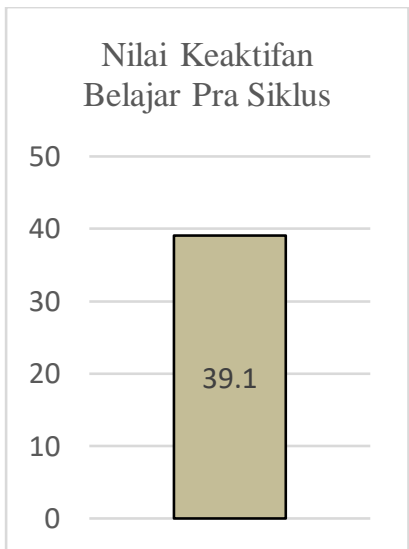

Gambar 2: Diagram Nilai Keaktifan Belajar Pra Siklus

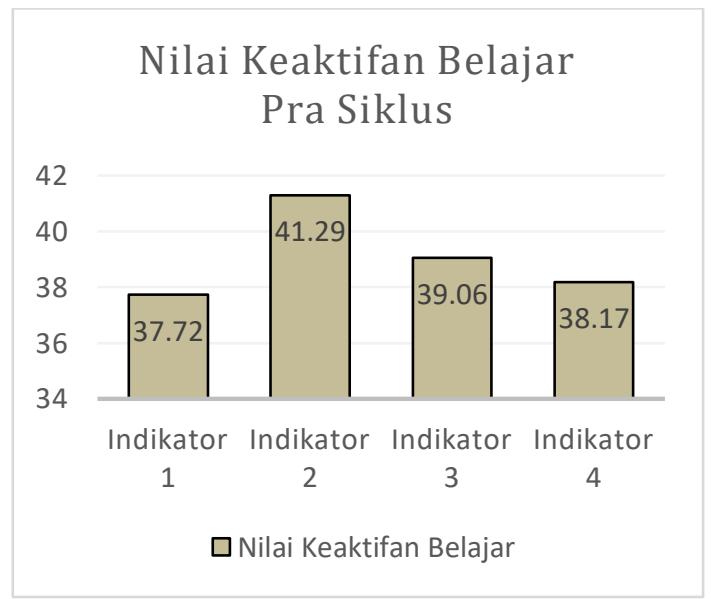

Gambar 3: Diagram Nilai Keaktifan Belajar Pra Siklus Tiap Indikator

Berbasis data keaktifan belajar peserta didik yang tergambar dalam tabel di atas, maka dilakukanlah tindakan dalam bentuk pembelajaran dengan menggunakan model Time Token dengan melewati dua tahapan atau siklus. Masing-masing siklus mengandung empat tahapan yakni tahap planning, acting, observing dan reflecting (Ni'mah, 2017).

\section{Siklus I}

Pada tahap planning dilakukan pencermatan dan pemantapan pada persiapan RPP dan materi yang mau dipelajari, perlengkapan pendudkung dalam pembelajaran, dan mendiskusikannya bersama guru kelas 5 mengenai mekanisme pembelajaran yang mau dilaksanakan. Hasil komunikasi dan diskusi bersama guru menghasilkan keputusan bahwa penelitian ini akan dilaknsakan secara kolaboratif bersama guru wali kelas 5 .

Setelah segala kegiatan dalam tahap perencanaan dilksanakan maka langlkah selanjutnya adalah tahap acting berupa pelaksanaan pembelajaran dengan menggunakan model pembelajaran Time Token dengan mengacu pada langkah-langkah yang telah disusun secara teratur dalam RPP. Kegiatankegiatan penting dalam model ini meliputi kegiatan peserta didik mendiskusikan materi yang dipelajari dan dilaporkan di depan kelas, setiap peserta didik dibagikan kartu berisi pertanyaan dan akan ditunjuk secara acak dan bergantian oleh guru, untuk menjawab pertanyaan yang tertera di dalam kartu tersebut. Ketika peneliti melaksanakan tindakan berupa pembelajaran dengan model Time Token bersama peserta didik, proses pembelajaran itu diamati dengan menggunakan panduan obervasi. Hal ini dilakukan untuk mengukur tingkat keterlaksanaan pembelajaran berdasarkan 
362 Penerapan Model Pembelajaran Time Token Dalam Upaya Meningkatkan Keaktifan Belajar PPKn Peserta Didik di Sekolah Dasar-Agustinus F.Paskalino Dadi, Maria Kewa

DOI: https://doi.org/10.31004/basicedu.v5i1.703

langkah-langkah pembelajaran Time Token dan mengukur tingkat keaktifan belajar perserta didik selama melaksanakan pembelajaran. Berdasarkan hasil observasi terhadap kedua hal tersebut maka ditemukan bahwa nilai keaktifan belajar peserta didik pada siklus I sebesar 69,7 dan tingkat keterlaksanaan pembelajaran dengan model Time Token adalah 76,7. Nilai tersebut dapat terlihat pada gambar 4 dan 5.

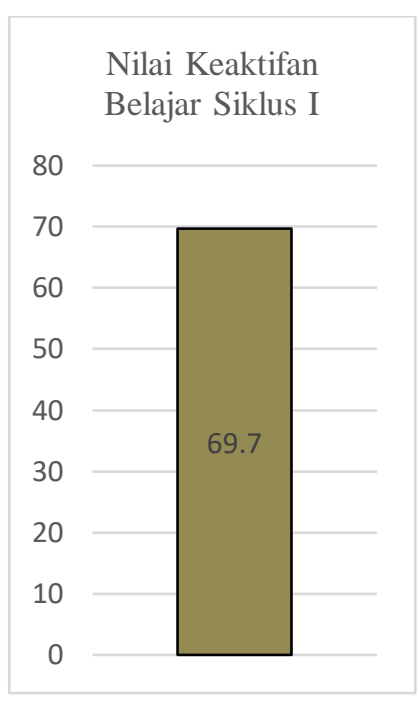

Gambar 4: Diagram Nilai Keaktifan Belajar Siklus I

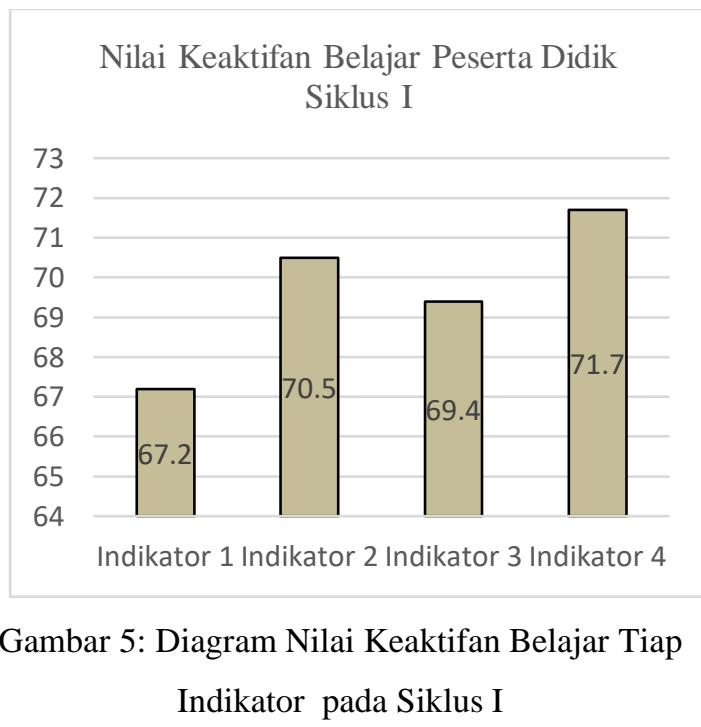

Selain keaktifan belajar peserta didik, observasi juga dilakukan untuk mengukur tingkat keterlaksanaan pembelajaran dengan model Time Token. Hasil observasi menunjukkan bahwa tingkat keterlaksanaan pembelajaran berada pada kategori tinggi dengan nilai 76,7 (bdk. gambar 6).

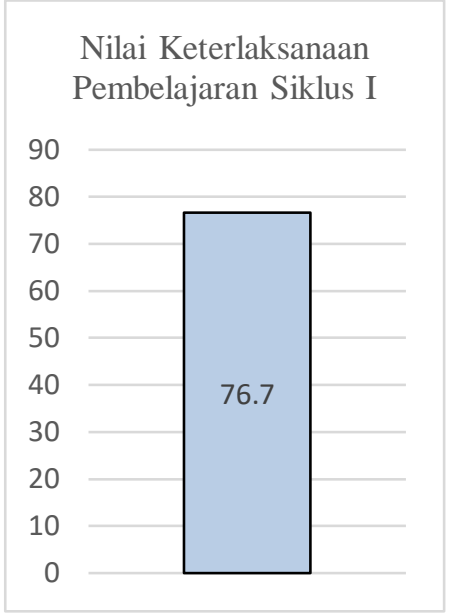

Gambar 6: Diagram Nilai Keterlaksnaan Pembelajaran dengan Model Time Token

Berdasarkan observasi, selanjutnya dilakukan proses refleksi (reflecting). Hasil refleksi menunjukkan bahwa telah terjadi perubahan kekatifan belajar peserta didik dalam pembelajaran namun tingklat perubahan yang dialami belum signifikan. Nilai keaktifan belajar peserta didik dalam pembelajaran PPKn telah mengalami peningkatan sebesar 30,6 namun masih belum maksimal karena masih berada pada kriteria cukup. Faktor penyebab masih belum optimalnya keaktifan belajar antara lain peserta didik lamban menyesuaikan diri dengan model pembelajaran yang baru, peserta didik masih dipengaruhi oleh perilaku lama yang kurang aktif dalam pembelajaran, kurangnya sosialisasi dan penjelasan guru tentang proses dan mekanisme pembelajaran dengan model Time Token.

\section{Siklus II}

Berdasarkan hasil refleksi terhadap pelaksanaan dan hasil dari pembelajaran pada Siklus I, maka dilakukan perbaikan berupa penjelasan yang lebih komprehensif tentang mekanisme pembelajaran dengan model Time Token dan memotivasi peserta didik untuk aktif dalam pembelajaran.

Tahap siklus II dimulai dengan tahapan perencanaan dengan menyusun jadwal dan 
363 Penerapan Model Pembelajaran Time Token Dalam Upaya Meningkatkan Keaktifan Belajar PPKn Peserta Didik di Sekolah Dasar - Agustinus F.Paskalino Dadi, Maria Kewa

DOI: https://doi.org/10.31004/basicedu.v5i1.703

melaksanakan kegiatan sosialisasi yang komprehensif tentang mekanisme pembelajaran dengan model Time Token. Selanjutnya dilakukan pelaksanaan pembelajaran dan observasi terhadap proses pembelajaran tersebut. Berdasarkan hasil observasi terhadap pelaksanaan pembelajaran pada Siklus II maka ditemukan hasil berupa adanya peningkatan keaktifan belajar pada peserta didik dalam pembelajaran PPKn dan peningkatan nilai keterlaksnaan pembelajaran. Hal itu dibuktikan dengan nilai keaktifan belajar yang meningkat dari angka 69,7 dengan kategori cukup menjadi 85,4 dengan kategori sangat tinggi. Nilai keterlaksnaan pembelajaran meningkat dari 76,7 dengan kategori tinggi menjadi 95 dengan kategori sangat tinggi. Data hasil observasi pada siklus II dijabarkan dalam gambar 7, 8 dan 9 .

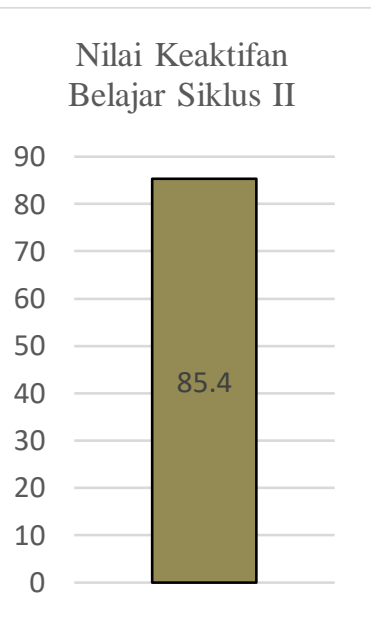

Gambar 7: Diagram Nilai Keaktifan Belajar Siklus II

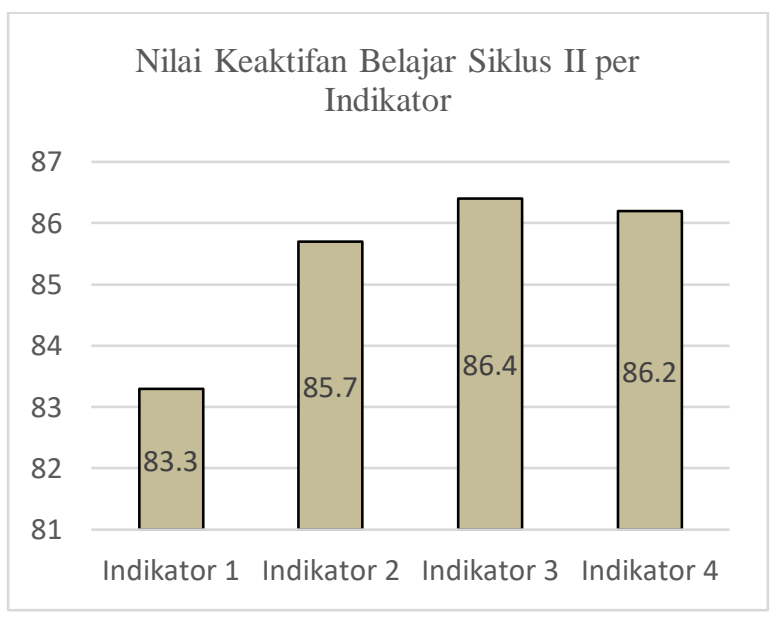

Gambar 8: Diagram Nilai Keaktifan Belajar Siklus II

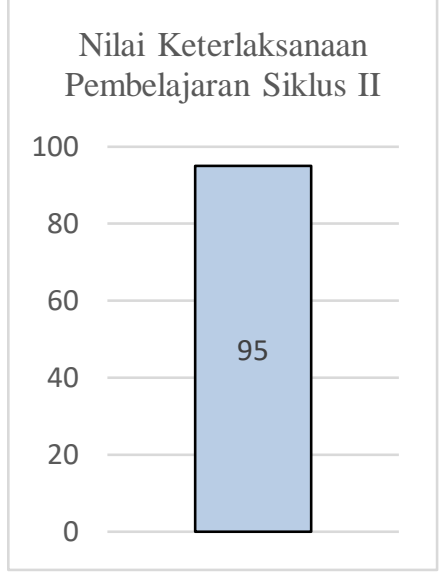

Gambar 9: Diagram Nilai Keterlaksnaan Pembelajaran dengan Model Time Token

\section{Keaktifan Belajar PPKn Peserta Didik Kelas 5 SD GMIT Ende 4 Setelah Penerapan Model} Pembelajaran Time Token

Pembelajaran PPKn adalah salah satu bidang pembelajaran yang ada di Sekolah Dasar. Substansi dari PPKn adalah hal-hal menyangkut nilai-nilai Pancasila dan pengayatannya serta topik-topik yang berkaitan dengan kehidupan warga negara. Fokus perhatian utama PPKn bukan hanya pada pengetahuan akan Pancasila dan topik kewarganegaraan melainkan juga pada aspek perilaku dan tindakan yang menunjukkan dirinya sebagai warga negara yang baik dan menjunjung tinggi nilai Pancasila.

Konsekuensi dari cakupan pembelajaran PPKn yang demikian terlihat pada cara guru memperlakukan peserta didik dalam pemebelajaran. Guru cenderung memandang PPKn sebagai mata pelajaran sosial yang tidak membutuhkan aktivitas yang tinggi pada peserta didik. Peserta didik dipandang sebagai individu yang belum memiliki pengetahuan dan wawasan yang memadai tentang Pancasila dan aspek kewaragenagaraa sehingga metode pembelajaran yang diterapkan bersifat teacher centered. Guru sangat mendominasi proses pembelajaran dengan penejelasan yang bertele-tele dan membiarkan peserta didik hanya mendengarkan penjelasannya. 
364 Penerapan Model Pembelajaran Time Token Dalam Upaya Meningkatkan Keaktifan Belajar PPKn Peserta Didik di Sekolah Dasar - Agustinus F.Paskalino Dadi, Maria Kewa

DOI: https://doi.org/10.31004/basicedu.v5i1.703

Ceramah menjadi metode utama untuk mentransfer pengetahuan dan menarasikan contoh-contoh perilaku sebagai warga negara yang baik. Metode ini ternyata membuat peserta didik pasif, enggan bertanya, memberikan pendapat dan mengeksplorasi pengetahuannya. Pada hal sesungguhnya pembelajaran yang baik dan berkualitas adalah pembelajaran yang ditandai dengan adanya keterlibatan aktif dari peserta didik dalam setiap proses pembelajaran baik dalam bertanya, menjawab, menggali pengetahuan baru, berdiskusi dan menyampaikan gagasan atau pendapatnya.

Dalam kondisi ini, pembelajaran dengan model Time Token merupakan solusi yang sangat menjanjikan. Dengan menggunakan model Time Token, akan dibangun suasana belajar yang aktif, menarik dan menyenangkan. Peserta didik dimungkinkan untuk aktif bertanya, berbicara, mengeksplorasi pengetahuannnya secara mandiri dan seimbang. Tidak ada peserta didk yang mendominasi dan tidak ada lagi peserta didik yang hanya berdiam diri. Model ini membuat peserta didik aktif sejak memulai pembelajaran hingga mengakhiri pembelajaran, saling berbagi pengetahuan, saling menggali pengetahuan dan saling melengkapi dalam kerjasama kelompok maupun dalam diskusi kelas (Handayani, 2018; Mariammas et al., 2018; Nurhasanah et al., 2013).

Pendapat dan temuan tentang keunggulan model Time Token dalam meningkatkan keaktifan belajar peserta didik terbukti dalam hasil penelitian pada peserta didik kelas SD GMIT Ende 4. Model Time Token telah membawa perubahan yang positif dalam hal keaktifan belajar peserta didik kelas 5 pada pembelajaran PPKn. Peserta didik terpacu untuk berani bertanya kepada guru dan temannya, berani dan siap memberikan jawaban ketika guru menunjuk dirina untuk menjawab pertanyaan guru, aktif untuk menggali pengetahuan baru dalam sumber belajar yang dimilikinya atau dalam diskusi bersama teman, dan aktif bertanya kepada guru ketika belum memahami pembelajaran dan terlibat aktif dalam menyelesaikan tugas kelompok.

Peningkatan kekatifan belajar tersebut didukung dengan hasil pengukuran terhadap data keaktifan belajar yang diperoleh melalui observasi. Nilai keaktifan belajar PPKn terus meningkat seiiring dengan penerapan model Time Token. Pada kondisi awal sebelum melaksnakana pembelajaran dengan model Time Token, tingkat keaktifan belajar peserta didik berada pada ketegori sangat rendah dengan nilai 39,1. Setelah diterapkan model Time Token, nilai keaktifan belajar ini mengalami peningkatan menjadi 69,7 pada Siklus I, dan meningkat menjadi 85,4 pada Siklus II. Tingkat keaktifan belajar peserta didik yang pada awal berada pada ketagori sangat rendah mengalami peningkatan menjadi cukup dan selanjutnya mencapai kategori sangat tinggi.

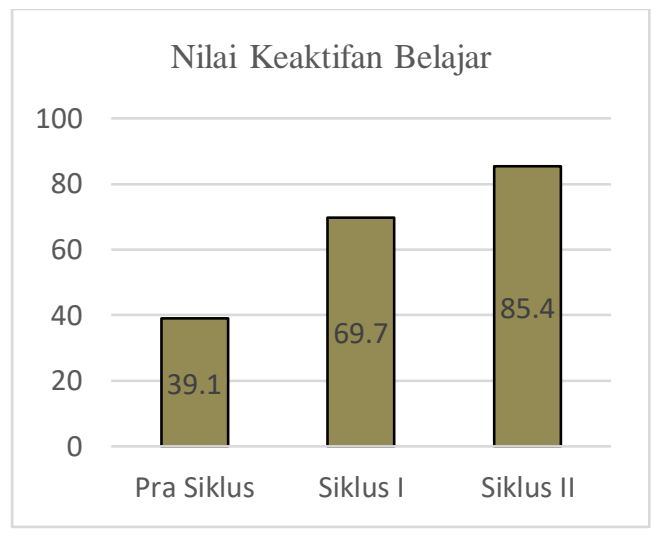

Gambar 10: Diagram Perbandingan Nilai Keaktifan Belajar Pra-Siklus, Siklus I dan Siklus II 

Peserta Didik di Sekolah Dasar - Agustinus F.Paskalino Dadi, Maria Kewa

DOI: https://doi.org/10.31004/basicedu.v5i1.703

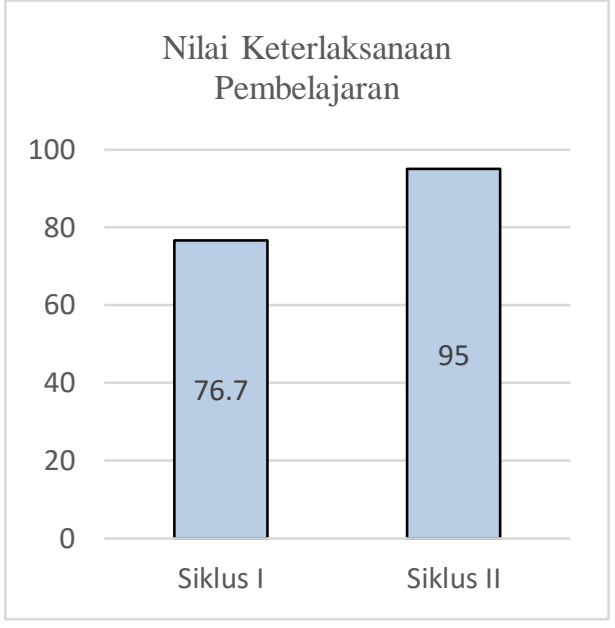

Gambar 11: Diagram Nilai Keterlaksnaan Pembelajaran Model Time Token

Selain keaktifan belajar peserta didik yang mengalami peningkatan, tingkat keterlaksnaan pembelajaran dengan model Time Token juga meningkat. Pada siklus I, tingkat keterlaksanaan pembelajaran mencapai nilai 76,7 dan meningkat menjadi 95 pada siklus II, setelah membuat perbaikan atas kekeurangan yang terjadi pada siklus I.

Berdasarkan nilai keaktifan belajar dan keterlaksnaaan pembelajaran pada amsing-masing pembelajaran, maka dapat dikatakan bahwa pembelajaran dengan model Time Token telah mencapai hasil yang optimal berupa peningkatan keaktifan belajar peserta didik dalam pembelajaran PPKn dari ketagori nilai yang sangat rendah menjadi sangat tinggi. Apa yang diyakini dari penerapan model Time Token sebagai upaya yang tepat dalam meningkatkan keaktifan belajar PPKn pada peserta didik kelas 5 SD GMIT Ende 4, telah terwujud.

\section{SIMPULAN}

Berdasarkan hasil penelitian tindakan kelas dengan judul Penerapan Model Time Token dalam Upaya Meningkatkan Kekatifan Belajar PPKn Peserta Didik Kelas 5 SD GMIT Ende 4, maka dapat disimpukan bahwa:

1. Model pembelajaran Time Token telah diimplementasikan dengan baik oleh guru dalam pembelajaran PPKn di Kelas 5 SD

GMIT Ende 4, baik pada siklus I maupun siklus II. Hal ini ditandai dengan nilai keterlaksnaaan pembelajaran pada siklus I adalah 76,7 (kategori tinggi) dan pada siklus II mencapai nilai 95 dengan kategori sangat tinggi.

2. Model Time Token terbukti merupakan model yang tepat sebagai solusi dalam upaya meningkatkan keaktifan belajar PPKn pada peserta didik kelas 5 SD GMIT Ende 4. Pembuktian dari kesimpulan ini terletak pada perolehan nilai keaktifan belajar PPKn dari peserta didik kelas 5 SD GMIT Ende 4 yang mengalami peningkatan dari nilai 39,1 pada periode pra siklus/pra tindakan, menjadi 69,7 (kategori cukup) pada siklus I dan meningkat lagi menjadi 85,4 (kategori sangat tinggi) pada siklus II.

\section{DAFTAR PUSTAKA}

Asnita, A., \& Khair, U. (2020). Penerapan Model Pembelajaran Time Token untuk Meningkatkan Keterampilan Berbicara Siswa. ESTETIK : Jurnal Bahasa Indonesia, $3(1)$, 53. https://doi.org/10.29240/estetik.v3i1.1501

Handayani, N. N. L. (2018). Pengaruh Model Pembelajaran Kooperatif Teknik Time Token Terhadap Aktivitas Belajar Dan Hasil Belajar IPA Siswa Kelas VI SD. Jurnal LAMPUHYANG, 9(2), 1-15.

Iriana. (2019). Penggunaan Model Pembelajaran Time Token Arends Untuk Meningkatkan Hasil Belajar dan Kemampuan Berbicara Siswa Kelas VII A SMP Negeri 1 Tanjung. Jurnal Langsat, 4(1), 1-8.

Istarani. (2012). Model Pembelajaran Inovatif, Referensi Guru Dalam Menentukan Model Pembelajaran. Media Persada.
Kandaga, $\quad \mathrm{T}$.
(2017).
Penerapan Model Pembelajaran Time-Token Untuk Meningkatkan Kemampuan Pemahaman dan 

Peserta Didik di Sekolah Dasar - Agustinus F.Paskalino Dadi, Maria Kewa DOI: https://doi.org/10.31004/basicedu.v5i1.703

Disposisi Matematis Siswa SMA. Edumatica, $7(01), 21-28$.

Latifah, S. (2015). Pengaruh Model Pembelajaran Kooperatif Tipe Time Token Berbantu Puzzle Terhadap Kemampuan Berpikir Kritis Peserta Didik Kelas X Pada Materi Gelombang. Jurnal Ilmiah Pendidikan Fisika Al-Biruni, 3(1), 13-23.

Mariammas, D., Zahara, R., \& Sritumini, B. A. (2018). Pengaruh Penggunaan Model Pembelajaran Time Token Terhadap Peningkatan Kemampuan Komunikasi Peserta Didik. Educare: Jurnal Pendidikan Dan Pembelajaran, 16(2), 35-42. http://jurnal.fkip.unla.ac.id/index.php/educare /article/view/229

Mungzilina, A. K., Kristin, F., \& Anugraheni, I. (2018). Penerapan Model Pembelajaran Problem Based Learning Untuk Meningkatkan Tanggung Jawab Dan Hasil Belajar Siswa Kelas 2 SD. NATURALISTIC: Jurnal Kajian Penelitian Pendidikan Dan Pembelajaran, 2(2), 184-195. https://doi.org/10.35568/naturalistic.v2i2.209

Nardiani, O., Sapir, \& Utomo, S. H. (2015). Penerapan Pembelajaran Metode Time Token Arends (TTA) Untuk Meningkatkan Kemampuan Bertanya dan Hasil Belajar Mata Pelajaran Ekonomi Siswa Kelas XI IS 4 di SMAN 1 BATU. Jurnal Pendidikan Ekonomi, 8(2), 82-90.

Ni'mah, Z. A. (2017). Urgensi Penelitian Tindakan Kelas Bagi Peningkatan Profesionalitas Guru: Antara Cita dan Fakta. Realita, 15(2), $1-11$.

Nurhasanah, N., Suherman, E., \& Lestari, P. B. (2013). Pengaruh Penerapan Model Pembelajaran Kooperatif Tipe Time Token terhadap Peningkatan Kemampuan Eksplorasi Matematika pada Siswa. Educare: Jurnal Pendidikan Dan Pembelajaran, 11(2), $10-19$.

Nurhayati, F., Sukmawati, \& Utami, S. (2014). Peningkatan Aktivitas Belajar Melalui Model Time Token IPS Kelas IV SD Negeri 06 Pontianak. Jurnal Pendidikan Dan Pembelajaran Khatulistiwa, 3(5), 1-15.

Oktaviani, S., Hariyani, S., \& Pranyata, Y. I. P. (2019). Penerapan Strategi Pembelajaran Time Token Untuk Meningkatkan Hasil Belajar Matematika Siswa Kelas X SMKN 2 Singosari. Rainstek Jurnal Terapan Sains \& Teknologi, 1(2), 54-63.
Oriza, R., Yamtinah, S., \& Ashadi, A. (2015). Penerapan Model Time Token Dilengkapi Jurnal Pribadi Untuk Meningkatkan Kemampuan Bertanya Dan Prestasi Belajar Siswa Pada Materi Pokok Stoikiometri Kelas X 3 SMA Muhammadiyah 1 Karanganyar Tahun Pelajaran 2014/2015. Jurnal Pendidikan Kimia Universitas Sebelas Maret.

Rachmadyanti, P. (2016). Penerapan Cooperative Learning Time Token Sebagai Upaya Meningkatkan Aktivitas Oral dan Hasil Belajar Mahasiswa PGSD Kelas D Angkatan 2013 Mata Kuliah Pendidikan IPS. Jurnal Widyagogik, 3(1), 19-32.

Santriana Son, R. S. (2019). Pengaruh Model Pembelajaran Kooperatif Tipe Time Token Terhadap Hasil Belajar Siswa SMP. Scholaria: Jurnal Pendidikan Dan Kebudayaan, 9(3), 284-291. https://doi.org/10.24246/j.js.2019.v9.i3.p284291

Shahn, S. (2018). Penerapan Strategi Pembelajaran Fire-Up Dapat Meningkatkan Hasil Belajar Peserta Didik Pada Pokok Bahasan Fluida di Kelas XI MIPA 1 SMA Negeri 2 Pekanbaru. Perspektif Pendidikan Dan Keguruan, 9(1), 20-26.

https://doi.org/10.25299/perspektif.2018.vol9 (1). 1424

Yetti, D. (2019). Meningkatkan Hasil Belajar IPA Siswa Melalui Pembelajaran Kooperatif Tipe Time Token Pada Materi Cahaya Di Kelas VIII C Sekolah Menengah Pertama Negeri 7 Batanghari. ANNABA': Jurnal Pendidikan Islam, 5(1), 21-42. 